\title{
What characterises high-growth firms in South Africa? Evidence from World Bank Enterprise Survey
}

\author{
A. Mthimkhulu and M. Aziakpono* \\ University of Stellenbosch Business School, Carl Cronje Drive Bellville 7535, Cape Town, South Africa \\ *To whom all correspondence should be addressed \\ Meshach.Aziakpono@usb.ac.za
}

\begin{abstract}
In the past two decades, considerable efforts have been made to promote small and medium enterprises as a catalyst for job creation in many countries, including South Africa. However, globally a growing body of evidence shows that only a small segment of small and medium enterprises in an economy accounts for 50 to $70 \%$ of net new jobs. Using the World Bank Enterprise Survey and logit and quantile regressions, this paper empirically explores the characteristics of high growth firms in South Africa. The study finds that firms that are less than 6 years create more jobs than the average firm in the sample. The results further suggest that the typical high-growth firms are black-owned.
\end{abstract}

\section{Introduction}

In the three decades since Birch (1981) showed that small businesses contribute more to employment than larger firms, many studies as reviewed by Storey (1994) and van Praag \& Versloot (2007) have affirmed the role of small businesses in job creation. Globally, the studies have bolstered public policy support for SMEs (small and medium enterprises). Davis, Haltiwanger \& Schuh (1996) however reveal that inasmuch as smaller firms create jobs they often fail to retain the new employees as most of the firms fold. In South Africa for instance, Kerr, Wittenburg \& Arrow (2013) find that between 2005 and 2011, firms with up to 20 employees created 75000 jobs quarterly but lost 110000 . Whether SMEs reduce unemployment is therefore a highly contested assertion (Mason \& Brown 2013; Shane 2009).

What perhaps offers an interesting perspective to discussions on enterprise development and job creation is the growing body of evidence showing that a small segment of enterprises in an economy accounts for 50 to $70 \%$ of net new jobs (Haltiwanger, Jarmin \& Miranda, 2013; Acs \& Mueller, 2008). There is debate on whether these high-growth firms are start-ups, small, medium or large. In fact, Audretsch (2012) and Walburn (2012) argue that little seems to be known about the characteristics of high-growth firms. Henrekson \& Johansson (2009: 230) identify only 20 studies on high-growth firms in the period 1990 to 2008 confirming the nascent state of the literature.

Nonetheless, directing developmental assistance to this small segment of firms or, alternatively, facilitating that other firms emulate their characteristics or practices could accelerate job creation and reduce the unemployment rate. Some authors (e.g. Coad, Daunfeldt, Hölzl, Johansson \& Nightingale, 2014) are cautious about the contribution of studies on high-growth firm to policy because a high-growth firm at time $t$ may not be such at $t+1$ so making it difficult for policies to target them. Daunfeldt \& Halvarsson (2014) and Hölzl (2014) empirically show this 'one-hit wonder' characteristic of highgrowth firms in Sweden and Austria respectively thus confirming the cautious authors' reservations. But the reservations are misplaced if the motivating curiosity of the studies is not the identity of a high-growth firm per se but its characteristics and practices which, when discerned successfully, could inform policy to target firms with similar traits in $t+1$ and thereafter thus contributing to policy.

Although the empirical literature is still emerging, highgrowth firms are drawing increasing interest of policy makers in developed economies. In developing countries where unemployment rates are perennially high, enterprise development policies tend to regard SMEs as homogenous such that policy interventions are generic. High-growth firms do not feature in policy discussions in developing countries and, except for the cross country study of 11 African countries by Goedhuys \& Sleuwaegen (2010), there is a dearth of related analyses in Africa.

In line with Goedhuys \& Sleuwaegen (2010), this paper seeks to stimulate discussions on high-growth firms in Africa. It focuses on South Africa excluded in Goedhuys \& Sleuwaegen (2010). Enterprise development is an important policy in South Africa to address unemployment and integrate previously disadvantaged groups into the economy by supporting their entrepreneurial efforts (NPC 2011; DTI 1995). The main policy framework supporting these goals is perhaps the BEE (Black Economic Empowerment) legislation which requires established organisations to spend proportions of their net revenues on enterprise development and procure some of their inputs from black-owned firms. A study into the characteristics of firms creating most jobs is thus important to inform policy on whether interventions have been useful and on how they can be improved. 
In order to determine the characteristics of firms creating most jobs, enterprise data from at least two periods is necessary. Such data in a reliable form is difficult to gather from small firms. A review of empirical studies on small businesses in South Africa reveals that studies are mostly qualitative typically reviewing changes in legislations and policies on enterprise development (Daniels 2004; Rogerson 2004; Rogerson 2008; McGrath 2005), describing characteristics of entrepreneurs (Rwigema \& Karungu, 1999), \& obstacles entrepreneurs face (Ladzani \& Netswera, 2009; Lotz \& Marais, 2007; Netswera 2010). When quantitative, studies seek to identify common attributes of obstacles faced by entrepreneurs often using factor analysis (Unger, Keith, Hilling, Gielnik \& Frese, 2009; Olawale \& Garwe, 2010; Nieman, Visser, \& van Wyk 2008).

Given the state of the small businesses literature in South Africa, the relationship between enterprise characteristics (for example level of education of the entrepreneur, firm size and age, access to finance etc.) and enterprise performance is underexplored. Relatedly, Nichter \& Goldmark (2009:1459) observe that in developing countries, little is known about the characteristics' 'relative importance or how they interact with each other' to influence growth. In light of the growing body of evidence on high-growth firms, it is perhaps more beneficial to relate certain characteristics to such firms and explore the interaction effects of the characteristics on the high-growth firms than the generality of enterprises.

To investigate the characteristics of firms that create more jobs in South Africa, a sample of 749 firms from the World Bank Enterprise Surveys is used. As is typical of most survey data it means that only characteristics in the World Bank Survey instrument could be explored. This may represent a potential selectivity bias as other attributes not captured in the instrument could not be explored. The sample is made up of firms with 5 to 250 employees. The analysis has two stages. The first stage seeks to provide an appreciation of the growth characteristics of firms that create more jobs than the sample average. In the first stage, firms are defined as being either outperformers if they generate more jobs than the sample average or underperformers if otherwise. A logit regression model is then employed to determine the characteristics of outperformers and how they differ from underperformers. The first stage also investigates the interactions effects of some of the characteristics on growth. The characteristics interacted are age group of the firm, size of the firm, ethnic origin of main owner, gender of main owner, level of education and experience of the manager or owner and the sector the firm operates in.

The second stage of the analysis determines characteristics of high-growth firms. High-growth firms are a subset of outperformers but there is no consensus in the literature on when growth is high-growth. As a result, definitions of highgrowth are often arbitrary hence the second stage of the analysis which uses quantile regression. Quantile regression accommodates the numerous definitions of high-growth in that the importance of each characteristic for firms in different levels of growth rates can be observed.

\section{Growth determinants: Theory and empirical evidence}

Studies that seek to explain the growth of firms can be classified into two theoretical perspectives: the Law of Proportionate Effect (or Gibrat's law) and the knowledge spillover theory of entrepreneurship (Lotti, Santarelli \& Vivarelli, 2008; Acs, Braunerhjelm, Audretsch \& Carlsson, 2009). Gibrat's law posits that growth rates are normally distributed such that no discernible characteristics can explain growth. Empirical analyses offer limited support for Gibrat's law with smaller and younger firms frequently found to outperform larger and older firms (Wagner 1992; Bigsten \& Gebreeyesus, 2007). Were Gibrat's law to perfectly hold then interventions to support SMEs would be difficult to justify. Indeed many authors argue that the most effective way of promoting enterprise growth is by ensuring that an enabling business environment exists and that such an enabling environment is realised if the regulatory burden on start-ups and smaller firms in, for example, registrations, taxes, and property rights is reduced (de Soto, 2000; Beck DemirgucKunt \& Maksimovic, 2005). While proponents of this view do not raise Gibrat's law as basis for their policy recommendations, there is mutual preference for letting firms attend to growth challenges unaided once the regulatory obstacles are removed.

The knowledge spillover theory of entrepreneurship suggests that growth can be explained by entrepreneur- and firmspecific characteristics (Acs et al., 2009). The theory is consistent with Jovanovic (1982) passive learning model where each firm at start-up is presumed to have a unique, random and unknown cost structures (and knowledge gaps) that the firm can only get to understand as it conducts its business. The cost structures determine the firm's scale of operations (i.e. size) as some knowledge is internally exploited or externalised when other employees leave with some of the knowledge to set up new firms. The aim of studies stemming from the knowledge spillover theory is to identify firm-specific factors that explain growth. Thus, studies proceeding from the knowledge spillover theory of entrepreneurship shy away from assessing the effects of macro-level factors like business regulations on growth. Instead, they look at the actual operations of the firm namely, who owns the firm, how the firm is managed and how it interacts with suppliers and customers.

Some empirical evidence on firm- and entrepreneur-specific attributes can be found in field experiments studies such as Banerjee \& Duflo (2010) and de Mel, McKenzie \& Woodruff (2013). Field experiment studies identify factors explaining growth by tracking the behaviour and transactions of entrepreneurs post-treatment where the treatment involves being granted microloans, receiving training or both. But since the field experiments studies focus more on microenterprises and draw almost exclusively from microfinance activities in very specific locations, generalising the results to SMEs is problematic. 
Empirical evidence on determinants of enterprise growth is extensive. In a review of early studies, Storey (1994) lists firm age, firm size, sector, legal form of enterprise, location, and ownership as key growth determinants. A review of studies since Storey (1994) shows an increasing number of variables being explored. It is however interesting to note that 'legal form of organisation' has over time become infrequently explored except in studies covering microenterprises. On the other hand, some determinants have gained importance in the literature and are being explored with increasing frequency. For instance, McPherson (1996) investigates if education, gender and age of entrepreneur explain growth. Brown et al. (2005) explore the growth effects of training and factors such as trade finance, loans accessed, previous work experience, and business association membership. Bigsten \& Gebreeyesus (2007) examine the effects of operational efficiency measures such as output per employee on growth. These factors are found to significantly explain growth. Most of the studies have however focused on access to finance as a determinant of growth. It would be interesting to explore if there are types of financing preferred by high-growth firms. Also, while many studies find access to finance to be the most serious obstacle to growth, corporate governance within emerging enterprises has been overlooked. Yet, governance issues are quite important when the firm solicits transactions with external stakeholders such as banks, suppliers and customers (Abor \& Adjasi 2007).

With regard to some findings on high-growth firms in the literature, Henrekson \& Johansson (2010) conclude after a review of the literature that it is age rather than size that defines high-growth firms and that if there is sector overrepresentation of such firms then the overrepresentation is more in the services than the technology sector. On the experience of the entrepreneur, Siegel, Siegel \& MacMillan (1993) show that it is experience within the enterprise's sector that is important.

\section{What is a high-growth firm?}

Growth can be based on variables such as sales, profits, value added, net assets or number of employees. The choice of the growth indicator depends on the empirical question and available data. The main issue is in defining high-growth: when is growth high-growth? Answers are many and arbitrary. In Siegel et al. (1993:172), a high-growth firm must double sales in its most recent three years. Siegel et al. (1993) however exclude companies with 'exceptionally high growth rates' so as not to skew the results.

Birch, Haggerty \& Parsons (1995:46) set revenues of US\$100 000 in the base year for the firm and state that subsequent sales growth must be at least $20 \%$ per annum for three years. According to the OECD (Organisation for Economic Cooperation and Development), a high-growth firm must increase its revenue by more than $20 \%$ per year for three consecutive years given that the firm is less than five years old and has at least 10 employees (OECD 2011). Barringer, Jones \& Neubaum (2005:664) use three year compound annual growth in sales of at least $80 \%$ to define high-growth.
Henrekson \& Johansson (2010:228) propose that highgrowth firms can be defined as a proportion of the fastest growing firms thus circumventing the arbitrary benchmarks. In spite of the different definitions, there seems to be consensus in the literature that high-growth firms represent 3 to $9 \%$ of firms in an economy. A global survey by GEM (Global Entrepreneurship Monitor) in 2011 reveals that 'high-growth entrepreneurs represent only $4 \%$ of the total entrepreneurs ... yet the businesses they have founded or coown created close to $40 \%$ of the total jobs generated by all entrepreneurs who responded to the survey' (GEM 2011:1). Goedhuys \& Sleuwaegen (2010: 38) explore how comparable the prevalence rate of high-growth firms in Africa is to developed economies and find the prevalence rate comparable at 5 to $9 \%$ of total firm distribution. This paper contributes to this emerging discussion of high-growth firms in Africa by focusing on South Africa where job creation is a subject of significant policy interest.

\section{Methodology}

\section{Determining growth}

Since the empirical problem is job creation, the study uses employment growth. Typically, studies that use employment growth (e.g. Dihn, Mavridis \& Nguyen, 2010; Ayyagari, Demirgüç-Kunt \& Maksimovic 2008) estimate growth as the $\log$ difference in the number of full-time employees between two periods:

$\mathrm{gr}_{\mathrm{emp}_{\mathrm{it}}}=\frac{\text { InEmp }_{\mathrm{it}}-\text { InEmp }_{\mathrm{i}, \mathrm{t}-1}}{\mathrm{~N}}$

where gr_emp $p_{i t}$ is the growth of firm $\mathrm{i}$ at time $\mathrm{t}, \mathrm{Emp}_{\mathrm{it}}$ is the number of its full-time employees at the end of later period, Emp $_{\mathrm{i}, \mathrm{t}-1}$ at the end of the earlier period and $\mathrm{N}$ is the number of years between the two periods.

The relative growth in Equation 1 will show higher growth rates for smaller firms because of their lower base. A smaller firm is in fact expected to experience rapid growth per the minimum efficient size hypothesis which posits that the smaller firm or a start-up must quickly reach a set operational scale to maintain presence in a given sector (Acs \& Audretsch 1989). When on the other hand an absolute measure of growth is used, i.e. the actual number of jobs created, a larger firm expectedly recruits more workers and perhaps play a more important role in reducing the absolute number of the unemployed. While the sheer numbers of smaller enterprises are presumed to result in more jobs, the demonstrated higher job-churning rate of smaller firms (Kerr et al., 2013) make the choice of using relative or absolute measures of growth important. To moderate overstating the growth propensity of small firms in relative measures and large firms in absolute measures, the Birch Index combines both measures as follows:

Birch Index $=\left(E m p_{t}-E m p_{t-1}\right) \frac{E m p_{t}}{E m p_{t-1}}$ 
This study follows Hölzl (2014; 2009) and Almus (2002) in using the Birch index in all estimations and uses the natural $\log$ of the index defined as:

Birch Index $=\left(\operatorname{lnEmp} p_{t}-\operatorname{lnEmp} p_{t-1}\right) \frac{\operatorname{lnEmp} p_{t}}{\operatorname{lnEmp} p_{t-1}}$ Outperformers and underperformers: Logit
regression

Before studying high-growth firms, it is perhaps important to appreciate the characteristics of firms that create more jobs than an average firm. The study refers to such firms as outperformers. To identify outperformers, the average growth rate for the Birch Index is determined and firms with above average growth, the outperformers, are coded 1 and 0 when below average.

Given a set of hypothetical characteristics informed by empirical literature, what are the odds that a firm will belong to outperformers against underperformers? Since it is already determined which firms belong to either group based on their observed growth, what in essence is sought by the question is whether the conditional factors will be useful in correctly assigning firms to the outperformers or to the underperformers category even when the actual growth were unknown. If for brevity sake all the conditional factors are referred to as $\mathrm{X}$, and the goal is to predict an outcome termed $\mathrm{Y}$ and coded 1 for outperformers (and 0 for underperformers), then the problem can be defined as

$\mathrm{P}=\mathrm{E}[\mathrm{Y}=1 \mathrm{IX}]=\mathrm{XB}$

The dichotomous outcome motivates the use of a logit regression model.

While the logit model is useful in contrasting outperformers to underperformers it is less so in exploring the interaction effects of conditional factors (or characteristics) as the interactions would results in a different classification of firms to outperformers and underperformers. To determine the interaction effects, an Ordinary Least Squares (OLS) regression is used as follow:

Birch Index $=\alpha+$ Interaction term +

business environment $+\varepsilon_{\mathrm{i}}$

where interaction term refers to a pair of variables from the list of firm and market characteristics, $\alpha$ is the intercept and $\varepsilon_{\mathrm{i}}$ the error term. The investigation then proceeds to observe the effect of the interaction term in the presence of all other firm characteristics, market characteristics and business environment variables:

Birch Index $=\alpha+$ Interaction term + all other firm and market characteristics + business environment $+\varepsilon_{\mathrm{i}}$

\section{High-growth firms: Quantile regression}

OLS is the commonly used method to estimate the effects of the factors on growth. The weakness of OLS is that it estimates 'the mean effects of the explanatory variables' on growth (Goedhuys \& Sleuwaegen, 2010: 40) such that when the subjects of the analysis have highly heterogeneous characteristics, the reported results have weak to unclear explanatory power. This problem is indeed evidenced by the very low R-squared statistic in most of the OLS-based studies. For example, a review of a dozen studies by Coad (2009) shows half of them with R-squared less than 5\% which according to Parker, Storey \& van Witteloostuijn (2010:208) suggests that 'the hypothesis that growth is a random walk cannot easily be dismissed'.

An alternative to OLS regression is quantile regression. Quantile regression is a special case of OLS in that it splits the dependent variable into percentiles which are arguably more homogenous than the full sample would be. Essentially, a standard linear regression model as in equation 6 is altered to:

Birch Index $_{i}=\beta_{0}^{q}+\beta_{1}^{\mathrm{q}}+\beta_{2}^{\mathrm{q}} \ldots \beta_{\mathrm{n}}^{\mathrm{q}}+\varepsilon_{\mathrm{i}}$

where $q$ is a percentile between 1 and $99 \%, \beta$ is the coefficient for each of the covariates and $\varepsilon_{\mathrm{i}}$ the error term. Since the focus is on firms that grow much faster than the generality of others, deciles starting at the 50 percentile will be analysed and attention in the interpretation of results will be given to the upper two deciles where high-growth firms reside.

\section{Data}

Data used are from Enterprise Surveys in 2007 for South Africa. The Survey covered 1057 (120 micro, 375 small, 366 medium and 196 large) in Cape Town, Durban, Johannesburg and Port Elizabeth. The study focuses on firms with 5 to 250 employees so that the study results can be compared to others in the literature on high-growth firms. The growth indicator was determined for only 749 firms which reported the number of employees in 2007 and 2003.

Table 4 has definitions and mean statistics of the characteristics that are evaluated. The characteristics are listed under four categories: firm, market and business environment. Some characteristics could be endogenous - a matter which this paper, following Goedhuys \& Sleuwaegen (2010), does not explore due to the limited data point given that the study uses only one survey data.

\section{Results}

Results contrasting outperformers and underperformers using the logit model are discussed in section 6.1 while the results on high-growth firms from the quantile regression model follow in 6.2.

From Table 1, outperformers are younger and smaller than underperformers. On average, outperformers start operation 
smaller (10 employees) than underperformers (23 employees). From other studies (e.g. Almus 2000; Goedhuys \& Sleuwaegen 2010) there is basis to suppose that outperformers would be innovative, ascribe to quality standards such as ISO 9002 etc. and use more modern technology proxied by a firm having its own website. This appears not to be the case for outperforming enterprises in South Africa with fewer outperformers using modern technology and holding lesser quality certifications for their products.
The work experience of managers does not seem to distinguish outperformer and underperformers in Table 1 perhaps because the study could not link the sector from which the experience of the manager was accrued from to the current firm (Siegel et al., 1993). However the top managers of outperformers are comparatively less educated. There is a comparatively larger proportion of Asian- and Africanowned firms that are outperformers than underperformers.

Table 1: Outperformers vs. underperformers - comparing means of characteristics

\begin{tabular}{|c|c|c|c|}
\hline & Variable & Outperformers & Underperformers \\
\hline & Total number of firms in the samples & 249 & 500 \\
\hline \multirow[t]{13}{*}{ Firm: } & Number of jobs created from 2003 to 2006 & 15.55 & 4.94 \\
\hline & Firm age in years & 14.63 & 19.55 \\
\hline & Percentage of firm held by main shareholder & 78.56 & 72.98 \\
\hline & Firms size with 1 being small and 2 medium & 1.55 & 1.67 \\
\hline & Sector: 1 is retail; 2 is services; 3 is manufacturing & 2.51 & 2.42 \\
\hline & Audit: $\%$ of firms with annual audit of accounts & 73.90 & 78.60 \\
\hline & Website: percentage of firms with own website & 40.96 & 47.20 \\
\hline & Education level (4 levels: 4th is university) & 1.98 & 2.17 \\
\hline & Training - percentage of firms that train workers & 34.54 & 45.80 \\
\hline & Experience of top manager in years & 14.75 & 15.65 \\
\hline & Gender - $\%$ of firms with female as shareholder & 18.78 & 22.52 \\
\hline & African-owned & 31.73 & 23.60 \\
\hline & European-owned & 36.95 & 48.00 \\
\hline \multirow[t]{9}{*}{ Market: } & Average sales (ZAR) & $20,400,000$ & $34,600,000$ \\
\hline & Management time per week spent on regulations $(\%)$ & 6.79 & 7.14 \\
\hline & Exports - $\%$ of direct exports in sales & 10.84 & 18.64 \\
\hline & Percentage of firms that applied for loan & 22.89 & 22.40 \\
\hline & Overdraft - \% of firms with overdraft & 50.60 & 60.60 \\
\hline & Percentage creditors' financing in working capital & 58.52 & 63.67 \\
\hline & Percentage of total trade credit in working capital & 22.01 & 23.03 \\
\hline & Percentage of firms visited by tax official & 38.96 & 48.40 \\
\hline & Number of years firms has known main supplier & 10.20 & 13.04 \\
\hline \multirow[t]{5}{*}{ Business environment: } & Crime as constraint on 1 to 4 scale; 4 is most serious & 2.15 & 1.94 \\
\hline & Percentage of firms paying for security & 69.88 & 81.80 \\
\hline & Electricity as constraint on 1 to 4 scale; 4 most serious & 1.06 & 1.21 \\
\hline & $\%$ of firms reporting having a generator & 13.51 & 21.91 \\
\hline & Transport as constraint on 1 to 4 scale; 4 most serious & 0.46 & 0.44 \\
\hline
\end{tabular}

Source: Authors' estimations from Enterprise Survey South Africa (2007)

It is difficult to draw conclusions on the market characteristics in Table 1. However, it is evident that outperformers suffer less regulatory intrusion proxied by lower percentage visits by tax officials and management time spent on regulatory issues. In particular, only $40 \%$ of outperformers are visited by tax officials compared to $48 \%$ of underperformers.

The preceding discussion gave an overview of characteristics of outperformers. The limitation of the discussion thus far is that it is not possible to infer the degree to which these characteristics differ between outperformers and underperformers. The logit regression results address this limitation.

\section{Characteristics of outperforming firms}

Table 2 reports the logit regression results. Four key observations emerge for discussion namely, number of employees a firm had at start-up, ethnic origin of main owner, managers' experience and business environment constraints. As noted in the previous section, outperformers are smaller at start-up than underperformers. Firms owned by previously disadvantaged South African are more likely to be outperformers and this likelihood is higher for blacks. All else being constant, a black-owned and an Indian-owned firm is 1.7 times and 1.6 times more likely to create a job than a white-owned firm. Relative to firms with managers who have more than 10 years' experience, enterprises with managers 
who have lesser experience are more likely to be outperformers. This likelihood is higher for the least experienced managers who are 1.8 time more likely to make their firms outperformers than manager with over 10 years of experience. With regard to business environment, none of the variables is statistically significant.

Table 2: Logistic regression results on the characteristics of outperformers and underperformers

\begin{tabular}{|c|c|c|c|c|c|}
\hline Logit on Birch Index & Coefficient & Odds ratio & P-value & \multicolumn{2}{|c|}{ 95\% Confidence interval for odds ratio } \\
\hline log of firm age & -0.449 & 0.638 & 0.102 & 0.373 & 1.093 \\
\hline log of no. of workers at start-up & -0.604 & 0.547 & 0.000 & 0.446 & 0.669 \\
\hline experience & 0.021 & 1.021 & 0.109 & 0.995 & 1.047 \\
\hline dummy: exports & -0.201 & 0.818 & 0.453 & 0.484 & 1.383 \\
\hline dummy: training & -0.206 & 0.814 & 0.285 & 0.558 & 1.187 \\
\hline trade credit & -0.002 & 0.998 & 0.722 & 0.989 & 1.008 \\
\hline dummy: up to secondary education & 0.151 & 1.163 & 0.545 & 0.714 & 1.894 \\
\hline dummy: vocational education & 0.080 & 1.083 & 0.717 & 0.703 & 1.669 \\
\hline dummy: university education & (base) & (base) & & & \\
\hline dummy: owner ethnic origin African & 0.529 & 1.697 & 0.022 & 1.080 & 2.668 \\
\hline dummy: owner ethnic origin Asian & 0.477 & 1.612 & 0.028 & 1.053 & 2.469 \\
\hline dummy: owner ethnic origin European & (base) & (base) & & & \\
\hline dummy: up to 5 years' experience & 0.589 & 1.801 & 0.097 & 0.899 & 3.610 \\
\hline dummy: 6 to 10 years' experience & 0.335 & 1.398 & 0.224 & 0.814 & 2.401 \\
\hline dummy: over 10 years' experience & (base) & (base) & & & \\
\hline dummy: young firms ( 1 to 5 years) & -0.043 & 0.958 & 0.937 & 0.332 & 2.762 \\
\hline dummy: mature firms (6 to 15 years) & -0.082 & 0.921 & 0.808 & 0.477 & 1.780 \\
\hline dummy: old firms (above 15 years) & (base) & (base) & & & \\
\hline working capital to debt & 0.001 & 1.001 & 0.890 & 0.991 & 1.010 \\
\hline$\%$ held by largest owner & 0.005 & 1.005 & 0.217 & 0.997 & 1.012 \\
\hline dummy: website & -0.383 & 0.682 & 0.064 & 0.455 & 1.023 \\
\hline dummy: overdraft & -0.179 & 0.836 & 0.337 & 0.579 & 1.205 \\
\hline dummy: audit & 0.002 & 1.002 & 0.994 & 0.646 & 1.553 \\
\hline dummy: gender & -0.157 & 0.855 & 0.484 & 0.551 & 1.326 \\
\hline $\log$ of 2003 sales & 0.158 & 1.171 & 0.042 & 1.006 & 1.364 \\
\hline Transport as a constraint & 0.102 & 1.108 & 0.345 & 0.896 & 1.369 \\
\hline crime as a constraint & 0.112 & 1.119 & 0.129 & 0.968 & 1.293 \\
\hline electricity as a constraint & -0.086 & 0.918 & 0.252 & 0.793 & 1.063 \\
\hline constant & -1.300 & & 0.428 & & \\
\hline R-squared & 0.104 & & & & \\
\hline Number of outperformers $(\mathrm{p}=1)$ & 249 & & & & \\
\hline Number of underperformers $(\mathrm{p}=0)$ & 500 & & & & \\
\hline
\end{tabular}

Source: Authors' estimations from Enterprise Survey South Africa (2007)

It is perhaps inadequate to merely observe the solo effect of a variable on growth. It is more informative to assess the interaction effects of, for instance, an ethnic group with some other characteristics on performance. The study observed 21 interaction terms. The results are presented in Table 3. Panel $\mathrm{B}$ of Table 3 shows the 7 interactions with positive and significant effects while Panel B shows 11 that are negative and significant when only the interaction term is run with only the business environment variables as controls. It is evident that the interactions terms of persistent importance are ethnic origin and firm age though some interaction with experience, sector and size are equally important.

When all variables enter the model, i.e. all other firm and market characteristics along with business environment as controls, Asian-owned young firms and European-owned young firms are significantly associated with growth. Although European-owned firms in the retail sector can be associated with job creation, the association disappears when firm and market variables enter the model. This is also the case with interactions of ethnic origin with experience where the positive association of African-owned firms diminishes when all other variables enter the model. Only 4 interactions are significant when all variables are modelled: Asian \&Young, European \&Young, Over-10-years-experience \&Young and Retail-sector \& medium. This shows that it is mainly young firms that create jobs.

An intriguing result is that when education interacts with firm age and with firm size, the effects are negative and these effects are significant if the manager of a medium-sized firm has less than secondary education. These results suggest with higher levels of education, managers could improve the performance of medium-sized enterprises. Mentorship programmes for enterprises owned or managed by women may also be important since female-owned firms with managers who have less than 5 years' experience significantly underperform. 
Table 3: OLS interactions significantly distinguishing outperformers and underperformers

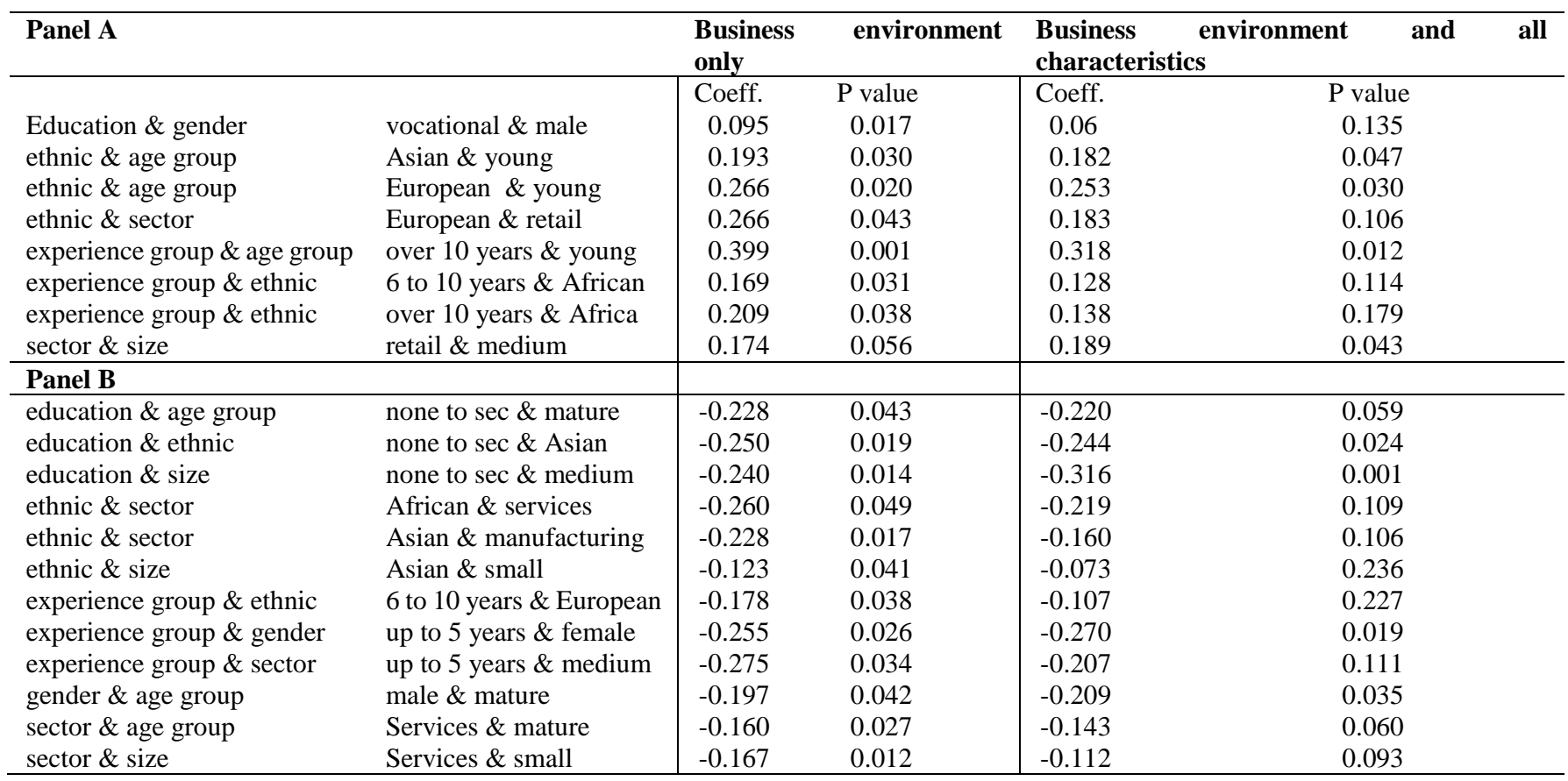

Source: Authors' estimations from Enterprise Survey South Africa (2007)

\section{Characteristics of high-growth firms}

The results of the quantile regression model are in Table 4. The first column reports the basic OLS regression typically used to investigate growth characteristics of firm. The next column reports effects of the characteristics on firms in the fifth decile or Q50 per the Table 4 notation. Given that highgrowth firms are at the right hand tail of the distribution of growth rates, the discussion on results focuses on the Q80 and Q90 results. The Q80 and the Q90 results in essence incorporate the numerous definitions of high-growth firms in the literature (Henrekson \& Johansson 2010:228).

With regard to experience, the results provide evidence that high-growth firms can be associated more with managers with up to 10 years' experience than above 10 years. The association is stronger with moderately experienced managers (i.e. managers with between 6 and 10 years). The results also provide evidence that African-owned firms are more likely to be high growth-firms. In relation to Asianowned, African-owned firms in Q80 and Q90 associate positively with growth. On the other hand European-owned firms underperform Asian-owned firms and the underperformance is significant at the top quantile while the outperformance by African-owned firms is significant.

With regard to education, the results show that in relation to low levels of education (i.e. up to secondary school) vocationally trained managers influence growth. Results show that enterprise performance is improved by in-house training programmes for workers. This is shown by the effects of training which turn positive at Q80 and Q90. No discernible patterns emerge on working capital related characteristics. However, firms with overdraft facilities have a consistently negative relationship with growth.

Goedhuys \& Sleuwaegen (2010) proxy innovation by whether a firm has a website or holds quality certifications such as ISO 9000 and find positive associations with highgrowth firms. The explanation for a positive association by Goedhuys \& Sleuwaegen (2010) is that websites mitigate transport and communication obstacles. The results of this study however show a consistently negative association of own-website with growth as with quality certification though the latter is positive at Q90. There is thus insufficient evidence in this study to associate these proxies of innovation with growth. Interestingly, transport as an obstacle has positive effects on growth and this effect is significant at Q90. It could be as Denrell \& Liu (2012) caution that high-growth firms may not necessarily reflect ability of entrepreneurs but structural faults in an economy which encourage opportunistic behaviours to take advantage of such faults than innovation. Importantly, high-growth firms are negatively affected by crime. 
Table 4: Results of quantile regression

\begin{tabular}{|c|c|c|c|c|c|c|}
\hline \multirow{3}{*}{ log of firm age } & OLS & Q50 & Q60 & Q70 & Q80 & Q90 \\
\hline & -0.111 & -0.034 & -0.039 & -0.095 & -0.136 & -0.181 \\
\hline & 0.027 & 0.428 & 0.232 & 0.164 & 0.061 & 0.140 \\
\hline \multirow[t]{2}{*}{ dummy: mature } & -0.031 & -0.072 & -0.059 & -0.007 & -0.032 & -0.051 \\
\hline & 0.633 & 0.199 & 0.165 & 0.938 & 0.754 & 0.769 \\
\hline \multirow[t]{2}{*}{ dummy: old } & 0.011 & -0.055 & -0.051 & 0.050 & 0.030 & 0.037 \\
\hline & 0.916 & 0.537 & 0.444 & 0.721 & 0.857 & 0.894 \\
\hline \multirow[t]{2}{*}{$\log$ of no. of workers at start-up } & -0.123 & -0.063 & -0.087 & -0.116 & -0.150 & -0.171 \\
\hline & 0.000 & 0.000 & 0.000 & 0.000 & 0.000 & 0.001 \\
\hline \multirow[t]{2}{*}{ experience } & 0.005 & 0.001 & 0.004 & 0.005 & 0.007 & 0.012 \\
\hline & 0.071 & 0.632 & 0.009 & 0.117 & 0.044 & 0.022 \\
\hline \multirow[t]{2}{*}{ dummy: 6 to 10 years' experience } & 0.021 & -0.004 & -0.036 & -0.077 & -0.075 & 0.074 \\
\hline & 0.702 & 0.932 & 0.317 & 0.304 & 0.386 & 0.605 \\
\hline \multirow[t]{2}{*}{ dummy: over 10 years' experience } & 0.002 & -0.002 & -0.064 & -0.104 & -0.162 & -0.086 \\
\hline & 0.977 & 0.968 & 0.153 & 0.254 & 0.117 & 0.614 \\
\hline \multirow[t]{2}{*}{ dummy: training } & -0.006 & -0.035 & -0.037 & -0.013 & 0.025 & 0.019 \\
\hline & 0.861 & 0.276 & 0.115 & 0.786 & 0.639 & 0.826 \\
\hline \multirow[t]{2}{*}{ dummy: up to secondary school } & 0.023 & 0.030 & 0.011 & 0.029 & -0.011 & 0.183 \\
\hline & 0.630 & 0.471 & 0.718 & 0.632 & 0.870 & 0.119 \\
\hline \multirow[t]{2}{*}{ dummy: vocational education } & 0.035 & 0.038 & 0.055 & 0.067 & 0.024 & 0.169 \\
\hline & 0.409 & 0.296 & 0.045 & 0.223 & 0.702 & 0.123 \\
\hline \multirow[t]{2}{*}{ dummy: Asian } & -0.100 & -0.018 & -0.001 & 0.009 & -0.060 & -0.327 \\
\hline & 0.035 & 0.656 & 0.968 & 0.884 & 0.396 & 0.003 \\
\hline \multirow[t]{2}{*}{ dummy: European } & -0.120 & -0.052 & -0.045 & -0.031 & -0.091 & -0.343 \\
\hline & 0.009 & 0.185 & 0.127 & 0.604 & 0.175 & 0.001 \\
\hline \multirow[t]{2}{*}{ dummy: gender } & -0.009 & -0.006 & -0.002 & 0.003 & 0.002 & 0.061 \\
\hline & 0.827 & 0.870 & 0.937 & 0.954 & 0.980 & 0.567 \\
\hline \multirow[t]{2}{*}{ dummy: exports } & -0.005 & 0.007 & -0.026 & -0.061 & -0.008 & 0.056 \\
\hline & 0.914 & 0.870 & 0.405 & 0.336 & 0.910 & 0.640 \\
\hline \multirow[t]{2}{*}{ trade credit } & -0.001 & -0.002 & 0.000 & 0.000 & -0.001 & -0.002 \\
\hline & 0.309 & 0.055 & 0.920 & 0.768 & 0.344 & 0.385 \\
\hline \multirow[t]{2}{*}{ working capital to debt } & -0.001 & 0.000 & 0.000 & 0.000 & -0.001 & -0.001 \\
\hline & 0.456 & 0.990 & 0.927 & 0.964 & 0.500 & 0.516 \\
\hline \multirow[t]{2}{*}{$\%$ held by largest owner } & 0.000 & 0.000 & 0.000 & 0.000 & 0.000 & 0.000 \\
\hline & 0.781 & 0.534 & 0.585 & 0.871 & 0.705 & 0.836 \\
\hline \multirow[t]{2}{*}{ dummy: audit } & -0.017 & -0.015 & -0.001 & 0.008 & -0.016 & -0.120 \\
\hline & 0.694 & 0.685 & 0.984 & 0.879 & 0.800 & 0.191 \\
\hline $\log$ of 2003 sales & 0.013 & 0.023 & 0.029 & 0.011 & 0.019 & 0.016 \\
\hline & 0.370 & 0.082 & 0.004 & 0.573 & 0.402 & 0.671 \\
\hline overdraft & -0.070 & -0.027 & -0.025 & -0.016 & -0.004 & -0.095 \\
\hline & 0.059 & 0.396 & 0.299 & 0.736 & 0.946 & 0.306 \\
\hline website & -0.074 & -0.036 & -0.014 & -0.082 & -0.043 & -0.018 \\
\hline & 0.065 & 0.297 & 0.576 & 0.110 & 0.459 & 0.847 \\
\hline Quality certification & & -0.022 & -0.014 & -0.026 & -0.025 & 0.098 \\
\hline & & 0.312 & 0.653 & 0.702 & 0.639 & 0.223 \\
\hline transport severity as a constraint & 0.021 & 0.000 & 0.003 & 0.019 & 0.048 & 0.143 \\
\hline & 0.316 & 0.991 & 0.803 & 0.482 & 0.130 & 0.002 \\
\hline crime severity as a constraint & 0.007 & 0.016 & 0.010 & -0.003 & -0.017 & -0.045 \\
\hline & 0.632 & 0.206 & 0.262 & 0.886 & 0.434 & 0.251 \\
\hline electricity as a constraint & 0.011 & -0.022 & -0.025 & -0.005 & 0.003 & 0.052 \\
\hline & 0.467 & 0.079 & 0.009 & 0.777 & 0.881 & 0.168 \\
\hline constant & 0.732 & 0.308 & 0.214 & 0.832 & 1.081 & 1.686 \\
\hline & 0.018 & 0.188 & 0.229 & 0.022 & 0.013 & 0.020 \\
\hline Adjusted R-squared & 0.126 & 0.057 & 0.072 & 0.087 & 0.119 & 0.192 \\
\hline Number of firms & 700 & 700 & 700 & 700 & 700 & 700 \\
\hline
\end{tabular}

Source: Authors' estimation from Enterprise Survey South Africa (2007)

\section{Implications for policy and research}

There are four findings that need further discussion for policy and research purposes. Firstly, the typical high-growth firm is likely to be African-owned. This may seem rather intuitive since $80 \%$ of the population is black. However, this is an important finding given that African-owned firms accounted for $26 \%$ of the 749 firms analysed against $29 \%$ and $44 \%$ for Asians and Europeans respectively. Secondly, it appears young firms create more jobs than mature firms but that the 
outperformance wanes as firms get to be above 15 years. A possible explanation for this is that the formal African-owned enterprise is to a large extent a post-1994 phenomenon. Government support, especially the BEE requirements, may have helped the emerging black owned firms. Interventions must also consider Asian-owned and white-owned firms that are young as their interaction effects with age are positive and significant.

Thirdly, small firms in the services sector underperform. This may suggest that the services sector has higher levels of minimum efficiency size which, in terms of number of employees, is above 19 employees. This raises an important question of how the small enterprises in the services sector can be supported. While Rogerson (2005 \& 2009) has investigated challenges for small firms in the tourism sector, little is known of constraints in the other services sub-sectors. Further research is necessary to address this gap. Finally, the study did not find sufficient evidence to associate exports with outperformance but this should not be taken to mean that exports do not influence growth. The problem as shown by Soderbom \& Teal (2003) is that few SMEs in Africa are exporters. There is therefore need for further research into barriers faced by few exporting SMEs and firms that attempt to.

In conclusion, it is hoped that this modest effort will encourage further studies on high-growth firms in South Africa. New studies would do well to take into account the limitations of the current study, one of which is that only characteristics in the World Bank Enterprise Survey instrument could be explored. Further research is therefore essential to explore other characteristics especially characteristics related to innovation.

\section{References}

Abor, J. \& Adjasi, C. 2007. 'Corporate governance and the small and medium enterprises sector: Theory and implication', Corporate Governance, 7(2):111-122.

Acs, Z. \& Mueller, P. 2008. 'Employment effects of business dynamics: Mice, Gazelles and Elephants', Small Business Economics, 30(1):85-100.

Acs, Z., Braunerhjelm, P., Audretsch, D. \& Carlsson, B. 2009. 'The knowledge spill-over theory of entrepreneurship', Small Business Economics, 32(1):15-30.

Acs, Z., Parsons, W. \& Tracy, S. 2008. High-impact firms: Gazelles revisited, SBAHQ-06-Q-0014. United States Small Business Administration.

Almus, M. 2002. 'What characterises a fast-growing firm? Applied Economics, 34(12):1497-1508.

Audretsch, B. 2012. Determinants of high-growth entrepreneurship. Report prepared for the OECD/DBA International Workshop on High-growth firms: local policies and local determinants, OECD.

Ayyagari, M., Beck, T. \& Demirguc-Kunt, A. 2003. Small and medium enterprises across the globe: A new database. Policy Research Working Paper 3127, The World Bank.
Ayyagari, M., Beck, T. \& Demirguc-Kunt, A. 2008. 'How important are financing constraints? The role of finance in the business environment', World Bank Economic Review, 22(3):483-516.

Banerjee, A. \& Duflo, E. 2010. 'Giving credit where it is due', Journal of Economic Perspectives, 24(3):61-80.

Barringer, B., Jones, F. \& Neubaum, D. 2005. ‘A qualitative content analysis of the characteristics of rapid-growth firms and their founders', Journal of Business Venturing, 20(5):663-687.

Beck, T., Demirguc-Kunt, A. \& Maksimovic, V. 2005. 'Financial and legal constraints to firm growth: Does firm size matter?', Journal of Finance, 60(1):137-77.

Bigsten, A. \& Gebreeyesus, M. 2007. 'The small, the young, and the productive: Determinants of manufacturing firm growth in Ethiopia', Economic Development and Cultural Change, 55(4):813884.

Birch, L. 1981. 'Who creates jobs?', The Public Interest, 65:3-14.

Birch, L., Haggerty, A. \& Parsons, W. 1995. Who's creating jobs? Boston: Cognetics Inc.

Brown, D., Earl, J. \& Lup, D. 2005. 'What makes small firms grow? Finance, human capital, technical assistance, and the business environment in Romania', Economic Development and Cultural Change, 54(1):33-71.

Coad, A. 2009. The growth of firms: A survey of theories and empirical evidence. Cheltenham: Edward Elgar.

Coad, A., Daunfeldt, S., Holzl, W., Johansson, D. \& Nightingale, P. 2013. 'High-growth firms: Introduction to the special section', Industrial and Corporate Change, 23(1):91-112.

Daily, C., McDougall, P., Covin, J. \& Dalton, D. 2002. 'Governance and strategic leadership in entrepreneurial firms', Journal of Management, 28(3):387-412.

Daniels, R. 2004. 'Financial intermediation, regulation and the formal microcredit sector in South Africa', Development Southern Africa, 21(5):831-849.

Daunfeldt, S. \& Halvarsson, D. 2014. Are high-growth firms one hit wonders? Evidence from Sweden. Working Paper, The Ratio Institute, Sweden.

Davis, S., Haltiwanger, J. \& Schuh, S. 1996. 'Small business and job creation: Dissecting the myth and reassessing the facts', Small Business Economics, 8(4):297-315.

De Mel, S., McKenzie, D. \& Woodruff, C. 2008. 'Returns to capital in microenterprises: Evidence from a field experiment', Quarterly Journal of Economics, 123(4):1329-1372.

De Soto, H. 2000. The mystery of capital: why capitalism triumphs in the west and fails everywhere else. Basic Books, New York.

Denrell, J. \& Liu, C. 2012. 'Top performers are not the most impressive when extreme performance indicates unreliability', Proceedings of the National Academy of Sciences USA, 109:93319336. 
Dihn, H.T., Mavridis, S.A. \& Nguyen, H.B. 2010. The binding constraint on firms' growth in developing countries. Policy Research Working Paper 5485, The World Bank.

DTI (Department of Trade and Industry). 1995. White paper for national strategy for the development and promotion of small businesses in South Africa. https://www.thedti.gov.za/sme_ development/docs/White_paper.pdf, Accessed 30 July 2014.

Gelb, A., Ramachandran, V., Shah, M. \& Turner, G. 2007. What matters to African firms? The relevance of perception data. Policy Research Working Paper 4446, The World Bank.

GEM (Global Entrepreneurship Monitor). 2011. High-impact entrepreneurship global report. http://www.gemconsortium.org/ docs/download/295, Accessed 30 July 2014.

Goedhuys, N. \& Sleuwaegen, M. 2010. 'High-growth entrepreneurial firms in Africa: A quantile regression approach', Small Business Economics, 34(1):31-51.

Haltiwanger, J., Jarmin, R. \& Miranda, J. 2013. 'Who creates jobs? small vs. large vs. young', Review of Economics and Statistics, 95(2):347-361.

Henrekson, M. \& Johansson, D. 2010. 'Gazelles as job creators: A survey and interpretation of the evidence', Small Business Economics, 35(2):227-244.

Hölzl, W. 2009. 'Is the R\&D behaviour of fast-growing SMEs different? Evidence from CIS III data for 16 countries', Small Business Economics, 33(1):59-75.

Hölzl, W. 2014. 'Persistence, survival and growth: A closer look at 20 years of fast-growing firms in Austria', Industrial and Corporate Change, 23(1):199-231.

Jovanovic, B. 1982. 'Selection and the evolution of industry', Econometrica, 50:649-670.

Kerr, A., Wittenburg, M. \& Arrow, J. 2014. 'Job creation and destruction in South Africa', South African Journal of Economics, 82(1):1-18.

Ladzani, W. \& Netswera, G. 2009. 'Support for rural small businesses in Limpopo Province, South Africa', Development Southern Africa, 26(2):225-239.

Lotti, F., Santarelli, E. \& Vivarelli, M. 2009. 'Defending Gibrat's Law as a long-run regularity', Small Business Economics, 32(1):3144.

Lotz, O. \& Marais, L. 2007. 'Manufacturing enterprises and marketing planning in a mining area of the North West Province, South Africa: Lessons for local business support centres', Development Southern Africa, 24(5):693-706

Mason, C. \& Brown, R. 2013. 'Creating good public policy to support high-growth firms', Small Business Economics, 40:211-225.

McGrath, S. 2005. 'Skills for productive citizenship for all: the place of skills development for micro and small enterprises in South Africa', Journal of Education and Work, 18(1):111-124.

McPherson, A, 1996. 'Growth of micro and small enterprises in Southern Africa', Journal of Development Economics, 48(2):253277.
Netswera, F. 2010. 'Perceptions of Johannesburg small business operators about their small business support systems', South Africa Journal of Business Management, 32(4):31-37.

Nichter, S. \& Goldmark, L. 2009. 'Small firm growth in developing countries’, World Development, 37(9):1453-1464.

Nieman, G., Visser, T. \& van Wyk R. 2008. 'Constraints facing tourism entrepreneurs in South Africa: A study in the Gauteng and Mpumalanga provinces, South Africa', Development Southern Africa, 25(3):283-296.

NPC (National Planning Commission). 2011. National Development Plan: vision for 2030. www.npconline.co.za/medialib /downloads/home/NPC\%20National\%20Development $\% 20 \mathrm{Plan} \% 2$ 0Vision\%202030\%20-lo-res.pdf, Accessed 30 July 2014.

OECD (Organisation for Economic Co-operation and Development), 2011. High-growth enterprises rate. http://www.oecd-ilibrary.org/industry-and-services/entrepreneur ship-at-a-glance-2010_9789264097711-en, Accessed 30 July 2014.

Olawale, F. \& Garwe, D. 2010. 'Obstacles to the growth of new SMEs in South Africa: A principal component analysis approach', African Journal of Business Management, 4(5):729-738.

Parker, S., Storey, D. \& van Witteloostuijn, A. 2010. 'What happens to gazelles? The importance of dynamic management strategy', Small Business Economics, 35(2):203-223.

Rogerson, C. 2004. 'The impact of the South African government's SMME programmes: A ten-year review (1994-2003)', Development Southern Africa, 21(5):765-784.

Rogerson, C. 2005. 'Unpacking tourism SMMEs in South Africa: Structure, support needs and policy response', Development Southern Africa, 22(5):623-642.

Rogerson, C. 2008. 'Tracking SME development in South Africa: Issues of finance, training and regulatory environment', Urban Forum, 19:61-81.

Rogerson, C. 2009. 'Mega-events and small enterprise development: The 2010 FIFA World Cup opportunities and challenges', Development Southern Africa, 26(3):337-352.

Rwigema, H. \& Karungu, P. 1999. 'SMME development in Johannesburg's Southern Metropolitan Local Council: An assessment', Development Southern Africa, 16(1):107-124.

Shane, S. 2009. 'Why encouraging more people to become entrepreneurs is bad public policy', Small Business Economics, 33(2): 141-149.

Siegel, R., Siegel, E. \& MacMillan, I. 1993. 'Characteristics distinguishing high-growth ventures', Journal of Business Venturing, 8(2):169-180.

Sleuwaegen, L. \& Goedhuys, M. 2002. 'Growth of firms in developing countries, evidence from Cote d'Ivoire', Journal of Development Economics, 68(1):117-135.

Soderbom, M. \& Teal, F. 2003. 'Are manufacturing exports the key to economic success in Africa?', Journal of African Economies, 12(1):1-29. 
Storey, D. 1994. Understanding the small business sector. Chapman and Hall.

Unger, J., Keith, N., Hilling, C., Gielnik, M. \& Frese, M. 2009. 'Deliberate practice among South African small business owners: Relationships with education, cognitive ability, knowledge and success', Journal of Occupational and Organizational Psychology, 82(1):21-44.

Van Praag, M. \& Versloot, P. 2007. 'What is the value of entrepreneurship? A review of recent research', Small Business Economics, 29(4):351-382.

Wagner, J. 1992. 'Firm size, firm growth, and persistence of change: testing Gibrat's Law with establishment data from Lower Saxony, 1978-1989', Small Business Economics, 4(2):125-131.

Walburn, D. 2012. 'Public policy and high growth firms', Local Economy, 27(4):329-331.

WBES data (The World Bank Enterprise Surveys). 2007. http://www.enterprisesurveys.org, Accessed 16 April 2014. 